\title{
デカルト哲学における情念と身体運動： 習性と予備修練に着目して
}

\author{
林洋輔
}

Yosuke Hayashi: The passions of the soul and bodily movements in the philosophy of René Descartes: From the viewpoint of habit and forethought. Japan J. Phys. Educ. Hlth. Sport Sci. 58: 617-635, December, 2013

\begin{abstract}
In the present study, an attempt was made to clarify a process of improving bodily movements in the context of physical education, centering on René Descartes' (1596-1650) theory of the passions of the soul. In the study of physical education philosophy, some attempts have been made to reconsider the mind-body relationship proposed by Descartes. To date, however, there has been little discussion about the passion of the soul theory from the viewpoint of an individual's bodily movements. Accordingly, it seems informative to examine a process of changing bodily movements from the philosophical perspective of Descartes.

The passion of desire and wonder, according to Descartes, has a profound influence on bodily movements, because, according to him, if the soul desires anything, the whole body becomes more agile and ready to move than without such desire. Curbing our desire for wonder disposes us to acquire scientific knowledge, thus leading us to achieve a specific aim. So we humans strive to control passion, desire and wonder through reason. Descartes also indicated the effect of habit, which leads us to change our bodily movements. Habits are applied not only in animals, but also humans. Therefore, these should be utilized for changing or improving our bodily movements. In addition, forethought can make our bodily movements more appropriate, because if we take care to be aware of our desire, which is dependent only on us, and seek to gain a goal as a result for it, we can enjoy the passion of joy, which brings pleasant emotion recognized by the soul. Bodily movements can thus change in a series of processes.

More enlightened discussion can ensue by elaborating on Descartes' mind-body theory and the passions of the soul.
\end{abstract}

Key words : body, emotion, desire, diligence キーワード：身体，情動，欲望，工夫

\section{I はじめに}

\section{人間——つまり任意の主体一一がさまざまな身} 体運動 les mouvements corporels を習得ないし は改変する際注1)，この主体のうちに存する情念 les Passions といったもろもろの感情や自由意 志，そして理性的思考などの心的な諸要素は身体 といかに関係するのだろうか。本論文はこの問い に対して解答することを研究の目的とする. とこ

筑波大学体育系

干305-8574＼cjkstart茨城県つくば市天王台 1-1-1

連絡先 林 洋輔
ろで本論文の独自性は次の 2 点にまとめること ができる、第 1 に，心身関係論およびのちにそ の定義がなされる情念へ着眼することによって, 主体が身体運動を改変する有り様を示そうとする ことである.というのは, 体育学の先行研究にお いて, 主体が任意の身体運動を習得する過程の探 求は分野の垣根を越えて行われてきたといってよ い注2)。ところが，主体のうちに存するもろもろ の情念やそれと理性的思考との関係に着目して議 論を行ったものはあまり見受けられない注 3 . こ

Faculty of Human Sciences, University of Tsukuba 1-1-1 Tennodai, Tsukuba, Ibarakai 305-8574 Corresponding author qqfs3s79@bridge.ocn.ne.jp 
れに対して本稿は情念あるいは理性的思考という これまで体育哲学の研究史において見過ごされて きた視点から議論を提案するという新たな視点を 有している. 第 2 に, 研究対象としてデカルト 哲学および彼の最晚年の著作である『情念論』に 着眼して議論が行われることである. 近年の体育 学においてはデカルトの心身関係論をいわゆる 「心身二元論」として退ける主張が論駁され注4), デカルト哲学に対する新たな受容のあり方につい て模索が行われている．他方，彼の『情念論』で は「実体の合一 unio substantialis」抢よび「心 身の合一l'union de l'âme et du corps」という心 身観を前提とし，現今の生理学や心理学抢よび倫 理学の範囲に及ぶ豊かな思索が行われている。 た，本稿で詳細に検討される「習性 habitude」 や「予備修練 préméditation」など主体における 身体運動の改变に示唆を与える多くの考え方が提 唱されており，体育哲学分野ではこの著作の検討 が望まれる課題として往昔から指摘されてい る注5)。これらの背景を踏をえ，本稿は『情念論』 を中心としたデカルト哲学を研究対象とし, 冒頭 の問題に対する回答を提出する.

議論の手順は以下の通りである。 まずデカルト に拈ける情念と心身観についての基本的な確認を 行ったのち，主体の身体運動にとりわけ強い影響 を与える情念について考察する，続いて主体にお ける身体運動のいわば改変契機となる「習性」に ついて検討し，この仕組みと身体運動の改変の関 係について考察していく．さらに理性的思考の実 質とも言うべき「予備修練」を通じて欲望 le désir を統御しつつ，主体が身体運動を改変する 有り様を明らかにする。そして，主体がこのよう な身体運動を行うことの目的についても考察す る。なぜなら，これを明らかにすることで，身体 教育を行うことの目的論に対しても新たな議論が 提起されうるからである，以上を踏をえた結論部 では総括および本稿の問いに対する回答，および 情念を研究対象とすることから拓かれる展望を指 摘する注6).

\section{II 情念と身体運動}

主体の身体運動に影響を及ぼす情念とは注7), どのようなものだろうか。この問いに対し, デカ ルトは『情念論』第一部第27項以下に抢いて情 念を次のように定義している。

情念を一般的に次のように定義 définir できる と思われる.すなわち, 精神の知覚, 感覚, 情動 des perceptions, ou des sentiments ou, des émotions de l'âmeであり, それらは, 特に精神に関 係づけられ，そして精気の何らかの運動によって par quelque mouvement des esprits 引き起こさ れ，維持され，強められる（デカルト，2008，p. 27, XI, 349).

情念とは主体の精神が直接的かつ受動的に受け 取る知覚であり, 感覚であり, 情動である.とい うのも，情念という語は「精神の受動 passions」 （デカルト，2008, p. 20, XI, 342）という意味を もち,「受動＝情念というこの語は通常, 精神そ のものに関係づけられる se rapportent à l'âme même 知覚だけを意味するように限定されてい る」（デカルト，2008, p. 25, XI, 348）からであ る. またデカルトによれば，情念を知覚と呼べる のは「精神の能動や意志でないすべての思考 toutes les pensées qui ne sont point des actions de l'âme, ou des volontés を意味する場合」（デカル ト, 2008, p. 27, XI, 349）であり，それは情念が 「精神と身体の密接な結合 l'étroite alliance qui est entre l'âme et le corps のために漠然として不明瞭 になっている知覚のなかに数えられる」からであ る（デカルト, 2008, p. 28, XI, 350).さらに, 情念が感覚と言いうるのは，たとえば熱や冷気な ぞの外的感覚 des sens extérieurs $の$ 対象と同じ ように，「精神のうちに受けとられ，精神によっ てそれと別様には autrement 認識されないから」 （デカルト，2008，p. 28，XI，350）である.また 情念を情動と呼ぶことは, 「いっそう適切 encore mieux」（デカルト，2008, p. 28, XI, 350）である 
とされる，なぜなら，「情動という呼び名は，精 神のうちに生じる変化のすべて，つまり精神に現 れるさまざまな思考のすべてにあてられる être attribué à tous les changements qui arrivent en elle, c'est-à-dire à toutes les diverses pensées qui lui viennent」(デカルト, 2008, p. 28, XI, 350) からである. 要するに, 情念とは主体の精神のう ちでも「精神の能動 les actions de l'âme」(デカ ルト, 2008, p. 21, XI, 342）である意志一それ は「本性上自由 libre de sa natureなので, けっ して強制されえないne peut jamais être contrainte」（デカルト，2008, p. 39, XI，359）と 『情念論』第一部第41項に抢いて規定されるもの 一とは異なる広範な心的領域を覆うものであ り,「精神の持ちうるあらゆる種類の思考のうち de toutes les sortes de pensées qu'elle peut avoir で, 情念ほど強烈に精神を動かし摇るがせるもの はほかにないからだ」（デカルト，2008，p．28， XI，350）とも述べられる. 主体に打ける身体運 動に影響を及ぼす情念とは, デカルトにおいては まず以上のような位置づけを与えられるものであ る.

ところで，この情念が「精神と身体の密接な結 合」を前提として生じるものであると言及された ことに着目したい，というのも，この「密接な結 合」とは体育学においてこれまで退けられてきた デカルトの心身観—いわゆる「心身二元論」 一とは異質のものであることを象徵的に言い表 しているからである.すなわちよく知られている ように, 『情念論』に拈いては情念の定義に関わ ることどもの「すべてをもっと完全に理解する entendre plus parfaitement toutes ces choses」 （デカルト，2008, p. 29, XI, 351）ために, 以下 の言及が行われている.

精神は真に身体全体に結合している l'âme est véritablement jointe à tout le corps こと, 精神が 身体のある部分にあって他の部分にないというの は正しくないこと. 理由のひとつは, 身体は一つ であり，ある意味で不可分であるからだ，身体の 諸器官は, どれか一つが除かれると全身に欠陥を
きたすほど, 器官相互に密接につながり, 配備 se rapporterされているためである. もう一つの 理由は, 精神の本性が, 身体をなしている物質 の, 拡がり〔延長〕にも, 次元にも, 他の特性に も, まったく関わらず, ただ身体諸器官の総体 tout l'assemblage de des organesにのみ関わるか らだ（デカルト，2008, p. 29, 括弧内訳文, XI, 351).

精神と身体一ここで言われる身体とは「身体 機械 la machine du corps」（デカルト, 2008, p. 33, XI, 354）という物理的物体としてのそれであ る—はともに実体 substantia として密接に合 一することで主体を構成する注 8 )。 また心身の相 関する有り様は「原初的概念 notions primitives」 （デカルト，2001c, p. 18, III, 665）あるいは「日 々のきわめて確かで明証的な経験によって〔われ われに〕示される certissima et evidentissima experientia quotidie nobis ostendit」(デカルト, 2009, p. 103, 括弧内訳文, V, 222) ものであ る注9). そしてこの心身の直接的な相関を前提と し,「精神は…, 精気, 神経さらには血液を介し て，身体の他のすべての部分に放射している elle rayonne en tout le reste du corps par l'entremise des esprits, des nerfs, et même du sang」（デカル ト, 2008, p. 33, XI, 354)注10). このような彼の心 身観は情念の働きを述べる際にも反映されてお り,『情念論』第一部第40項においては次の言及 が確認される。

…人間に打ける情念すべての抢もな効果 le principal effet de toutes les passions dans les hommes は, 情念が身体に準備させていること を, 精神にも意志するように促し仕向けること inciter et disposerであるのに注目する必要があ る.たとえば, 恐怖の感覚は逃走を意志するよ う, 大胆の感覚は戦いを意志するよう精神を促す し，その他も同様だ（デカルト, 2008, p. 39, XI, $359)$ 注11).

情念は気体状の血液である動物精気 des es- 
prits animauxによって脳内の「小さな腺 une petite glande」(デカルト, 2008, p. 30, XI, 351) —いわゆる松果腺——が摇らされることでまず はこの松果腺に密着する精神にさまざまな情念が 生じ注12), 次にその情念が松果腺を摇らし返すこ とで動物精気に作用し，さらにこの精気が諸神経 を介して筋肉に行き渡ることで主体の身体運動が 生じる注13)。そしてこの情念の発生原因としては 以下のように自己の外に存する人格としての他 者, つまり〈他人〉の存在が着眼されるべきであ る.というのも，『情念論』においては情念の発 生原因としての他人が以下のように言及されてい るからである。

感覚を動かす対象がわたしたちのうちにいろい ろな情念を引き起こすのは，対象のうちにあるい ろいろな性質すべてによるのではない，ただ，対 象がわたしたちを害したり益したりしうる多様な しかた，あるいは，一般にそれら対象がわたした ちに重要となる多様な仕方 des diverses façons qu'ils nous peuvent nuire ou profiter, ou bien en général être importants による（デカルト，2008, p. 52, XI, 372).

主体の感覚するすべてのものに対して情念が生 じるわけではない。むしろ，任意の主体にいわば 利害関係の生じる外的対象が存在することによっ て情念が生ずる．そしてこの事例における外的対 象とは他人にほかならない注14)。というのも， 『情念論』第二部以降に扔ける諸記述に扔いて, 主体における諸情念の発生抢よびその影響が他人 の介在を前提として語られるからである，ところ でデカルトが「基本情念 passions primitives」 （デカルト，2008，p. 60，XI，380） と呼ぶ基本的 な情念一デ゙カルトによれば，「単純で基本的な 情念は，驚き l'admiration，愛l'amour，憎しみ la haine, 欲望 le désir, 喜び la joie, 悲しみ la tristesse の 6 つだけであり，他のすべての情念 は，これら 6 つの情念のいくつかの複合，劣 いは種 des espècesである」（デカルト，2008， pp. 60-62, XI, 380)一のうちで主体における身
体運動の発現にとりわけ影響を及ぼすものは, 「欲望」ならびに「驚き」の情念である注15)。そ の理由として，第 1 に，「欲望」の情念はその発 生によって以下に見るように心蔵 le cœur や動物 精気と作用しあうことで主体の身体運動に影響を 及ぼすことが明らかだからである。第 2 に，「驚 き」の情念は次節で述べられる「習性」概念とい わば連携することによって，主体における身体運 動の改変に関与することが明らかだからである.

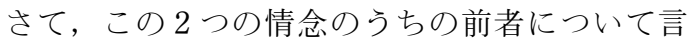
えば，「つねに未来 l'avenir に向かっている」(デ カルト， 2008, p. 55, XI, 375）欲望の情念は「ま だ手に入れていない善 un bien qu'on n'a pas encore を得ようと欲したり, 今後起こりうる悪を 避けようと欲したりする場合ばかりか，ただ，善 の保存, 悪の不在 la conservation d'un bien, ou l'absence d'un mal を願うだけの場合」(デカルト， 2008, p. 55, XI, 375）のすべてに及びうるもので ある。そしてこの欲望は，主体に扔ける身体運動 の発現においては，以下のような影響を及ぼすこ とになる。

欲望は他のいかなる情念よりも，激しく心蔵を ゆり動かし，多量の精気を脳にもたらす。これら の精気は, 脳から移って筋肉に流れ, 感覚すべて をいっそう鋭く rendent tous les sens plus aigus し，身体のすべての部分を動きやすく toutes les parties du corps plus mobiles する（デカルト, 2008, p. 86, XI, 403).

欲望の情念が他の情念にもまして身体運動を行 いやすくすることの理由が上のように言及されて いる. すなわち先行研究でもすでに指摘されたよ うに注16)，主体の身体運動における「欲望」の情 念の影響が確認される。ささらに言えば，欲望の情 念を有することによって「精神が何かを欲すると き，全身体 tout le corps が，欲望を持たないと きよりも機敏で動きやすくなる plus agile et plus disposé à se mouvoir」(デカルト, 2008, p. 94, XI，411）ばかりではなく，「身体がそうした状態 になると，それが精神の欲望をいっそう強く激し 
くする cela rend les désirs de l'âme plus forts et plus ardents」(デカルト, 2008, p. 94, XI, 411). このように，いわば目的的対象としての善の獲得 をめざして欲望の情念が主体の身体運動に深く関 与する注17)。そして後述のように，主体の理性的 思考によってこの欲望を統制するところに主体に 抢ける身体運動の改変の要諦が存していると結論 づけられるのである.

さて, 情念の統制による身体運動の改変には大 別して次の 2 つがその要因として主体に関係す る.すなわち第 1 に，いま述べた理性的思考に よって欲望を統制することに由来する一一言うな ら精神的側面における——身体運動の改变であ り，第 2 に, 次節で考察する「習性 habitude」 を通じたいわば身体的な側面からの身体運動の改 変である. 後者について, デカルトはある書簡で 次のように述べている.

われわれの精神と身体との間には，次のような 結合関係 liaisonがあること.すなわち，われわ れが生まれたときから身体のある運動に伴う思考 は, 今もな颃その運動を伴う。したがって同じ運 動が何か外的な原因によって身体のなかで再び引 き起こされると, 精神のなかにも同じ思考 les mêmes pensées を引き起こす. 反対に，われわ れが同じ思考を持つと，それは同じ運動を生む. そして結局, われわれの身体という機械 la machine de notre corps のつくりは, 喜び，ある いは愛, あるいは他のそれに似たものの思考を少 しでも持てば，情念に伴うと私が言った血液のさ まざまな運動を引き起こすのに必要な動物精気 を, 神経を介して全筋肉のなかに送るのに十分で あるようになっていること（デカルト，2001c, p. 185, IV, 408).

デカルトによれば，心身には逐次的な対応関係 のあることが確認される，したがって，任意の身 体運動を行うように主体の精神を任意の思考へと 仕向けることが検討されるべき課題として立ち現 れることとならう. なぜなら，任意の身体運動と は心身の対応を前提として発現することになるか
らである，そこで次節ではいわばそのメカニズム としての「習性」について，先に言及した「驚き」 の情念による影響をも踏をえながら検討を加えて みよう。

\section{III 習性亡身体運動}

主体の心身において対応関係の観られること は, デカルトの思想において往昔から見られたも のであった注18). 彼は晚年の書簡においてもま た，身体と結びついた精神の「特性 propriété」 （デカルト，2001b, p. 387, IV，604）について次 のように言及する。

精神の想念のそれぞれ chacune de ses pensées が，身体のなんらかの運動やその他の状態と連合 しあう associer avec quelques mouvements ou autres dispositions de ce corps ことができるため に, 同一の状態がべつの機会に身体のなかに現れ たとき, 精神 l'âme はそれによって動かされてま えとおなじ想念 la même pensée を導きだし, 逆 に同一の想念がまたふたたび現れたとき，身体が それによって動かされて，まえとおなじ状態を受 けいれる recevoir la même disposition というこ とにほかなりません，そのようなわけで，なにか ある言語を習得するさい, ひとは単語の綴りと か，発音とかいうような物質的な事柄 des choses matérielles を, その単語の意味というい わば想念と結びつけます。その結果のちになっ て，おなじ単語をふたたび耳にしたとき，われわ れはおなじ事物を頭に描くのであり, また同じ事 物を頭に描いたとき，おなじ単語を思いおこしま す（デカルト, 2001b, pp. 387-388, 一部改訳, IV, 604).

『情念論』第一部第44項において言語における 発音と観念との差異について示されるよう に注19), 身体運動—それは必ずしも全身を用い た運動に限られるものではない—と精神との対 応関係は確かなものとしてデカルトのうちにいわ ば息づいていたようである。すなわち,「精神に 
一定の対象を表象する représentent à l'âme certains objets 運動は, 自然的に，精神のうちに一 定の情念 certaines passions を引き起こす運動と 結びつけられている」（デカルト，2008， p. 49, XI, 369)。しかしながら，デカルトによれば必ず しもこのような心身の対応関係が主体に打石不 動のものとして位置づけられるわけではない，と いうのも，「習性 habitude によって，その運動か ら分離して，まったく違った別の運動と結びっけ ることができる」（デカルト，2008，p．49，XI， 369）からである，ところで，このような心身の 対応関係ならびにそれの後天的な改変について, それが主体における身体運動の改変にも有用であ るならば，いかなる論拠によってそのことが言え るのか。この問いについてデカルトは猟犬 un chienを事例として身体運動における「習性」の 効果を敷衍している。すなわち彼によれば，「動 物は理性 raison を持たないし，抢そらく何の思 考 pensée を持たない」（デカルト，2008，p. 50， XI，369）が，「わたしたちのうちに情念を引き起 こす精気や腺の運動すべて tous les mouvements des esprits et de la glande, qui excitent en nous les passions を，やはり具えている」（デカルト， 2008, p. 50, XI, 369）とされる.このことを前提 として以下の言及が行われる。

たとえば犬は生来, ヤマウズラ une perdrix を 見るとそれを追って走りたがり，銃声を聞くと逃 げたがる、にもかかわらず通常, 猟犬を訓練して ヤマウズラを見るととどまるようにし，次にヤマ ウズラを撃つとその音を聞いて鳥のほうへ駆ける ようにするのである. さて以上のことは, 各人に みずからの情念を統御することを学ぶ勇気を与え る donner le courage à un chacun d'étudier à régler ses passionsために, 知っておくのが有益で ある（デカルト， 2008, p. 50, XI, 370).

理性を持ち得ない猟犬は任意に訓練されること を通じ，これまでとは異なる動作をなしうるよう になる，すなわち，ヤマウズラを見ることによっ て生まれる情念と，それに対応する動物精気の運
動は後天的言うなら人為的な作用によって変化す る. 他方でこのような任意の対象へ向けられた後 天的な働きかけについて注20)，この仕組みは任意 の主体つまり身体運動を行う主体としての人間に 対しても同じく適用されるものである. デカルト は，このことを次のように指摘している.

理性を欠いた動物を，わずかの工夫で脳の運動 を変えることができるのだから，人間ではそれを さらに良くできるのは明らかだ，そして，最も弱 い精神の持ち主でも, 精神を訓練し導くのに十分 な工夫の積み重ねを用いるなら si on employait assez d'industrie à les dresser, et à les conduire, あらゆる情念に対してまさに絶対的な支配を獲得 できるのは明らかである（デカルト， 2008, p. 50, XI, 370).

諸動物における運動の改変において適用される 習性とは, 主体が自らの身体運動を改変する場合 においてもまた，情念への対処を反復的に訓練な いし工夫することで適用される，なぜなら，「わ れわれの身体機械 la machine de notre corps」（デ カルト, 2008, p. 33, XI, 339) の仕組みは数学と 物理とによって理解できるという意味において諸 動物と同質のものであり, 諸動物における運動に 対して適用される仕組みは，主体一つまり心身 の合一した人間という意味での主体一の身体に 対しても当てはまるからである. 要するに, 主体 の身体は精神による介入を踏まえた反復的な訓練 ないしは工夫を通じ，任意の身体運動を発現しう ることが示唆されていると言えよう注 21$).$

ところでこの習性とは，「ただ一度の行為によ って獲得することができ，長期の馴れ un long usage を要しない」(デカルト, 2008, p. 49, XI, 369）と指摘される．この「ただ一度の行為 une seule action」(デカルト, 2008, p. 49, XI, 369) とは，主体が「驚きl'admiration」（デカルト， 2008, p. 53, XI, 373）によって自らの身体運動を 改変することを指す。すなわち，この驚きの情念 が習性と深く関わり，さらに身体運動の改変にも 影響を及ぼすものといえるのである。というの 
も，この「驚き」の情念は習性と関係づけられる ことによっていわば学習の契機となりうるからで ある。このことを敷衍するならば，以下のように 議論を展開することができる.

「驚き」とは「あらゆる情念のうちで最初のも の la première de toutes les passions」(デカルト, 2008, p. 53, XI, 373) であり，それが有益である のは「それまで知らなかったことをわたしたちに 学ばせ「記憶 mémoire」にとどめさせる」（デカ ルト， 2008, p. 65, XI, 384）ことである.この論 点について先行研究によれば, 一方で「驚きとは 知的な情念 Wonder is $\cdots$ an intellectual passion」 (Morgan, 1994, p. 193) であるとともに，他方で は「認識の増大へ向けた刺激 a stimulus to increasing one's knowledge $」$ (Morgan, 1994, p. 194）であると指摘されている.すなわちデカル トに㧍ける「驚き」の情念には，教育的な含意が 存すると言ってよいだろう.というのは，上の先 行研究による主張はデカルトが「驚きの情念への 傾向をある程度もって生まれるのは, 知識の獲得 l'acquisition des sciencesにわたしたちを向ける ために良い」（デカルト，2008，pp. 66-67, XI, 385）とする言及からも確認されるからである.

また「驚き」の情念が教育の観点から着眼すべき ものであることは, 次のデカルトの言及からも確 認される，すなわち，驚くことへの傾向 inclinationについて，「できる限りこの傾向から逃れる nous délivrer よう努めなければならない」（デカ ルト，2008，p. 67，XI，385).なぜなら，第 1 に，「その不足は特殊な反省や注意によって補う こと suppléer à son défaut par une réflexion et attention particulière が容易であり, 現れた事物が そうした反省や注意に值すると判断されれば，つ ねにわたしたちの意志 volonté は知性 entendement をそうした反省や注意に向かわせることが できる」（デカルト，2008, p. 67, XI, 385）から である、第 2 に，「過度に驚くこと，ほとんどあ るいはをったく考慮する值うちのないものを知覚 して驚愕すること qu'on s'étonne, en apercevant des choses qui ne méritent que peu ou point d'être considérées」（デカルト, 2008, p. 66, XI, 385)
を通じて，「理性の使用を根こそぎ台なしにした り歪めたりしうる cela peut entièrement ôter ou pervertir l'usage de la raison」（デカルト，2008, p. 66, XI, 385）からである.さらに『情念論』第 二部第78項において言及されるように，「過剩な 驚きは，直さないでおくと習性になりうる peut passer en habitude」(デカルト, 2008, p. 68, XI, 386）ものであり，理性の使用を妨げる過剩な驚 きとして主体に定着するからである。このよう に，「驚き」の情念は一方において主体における 学習の契機をなすものである. しかしながら, 他 方において過剰な驚きは主体にとって有害であり うるゆえに矯正一一言うなら教育的な措置—の 求められるものである。それならば，このような 過唾な驚きを矯正するための方法として, デカル トはいかなるものを提示しているのであろうか. この問いに対しては, デカルトによる以下の応答 を検討することによって議論をさらに展開するこ とができる，というのは，デカルトの当該応答は 過剰な驚きに対する具体的な方策を示すものであ るばかりではなく, 理性による情念の統御という 観点において, 後にデカルトが言及する「予備修 練」にも関係する内容を含み持つからである.

まずデカルトは「過剩に驚くことを控えるため の治療法 remède pour s'empêcher d'admirer avec excès」(デカルト, 2008, p. 67, XI, 385) として, 「多くのものについての認識を得て d'acquérir la connaissance de plusieurs choses, きわめて異例 かつ奇異に見えるすべてのものについて考察する 訓練を積む de s'exercer en la considération ほか はない」(デカルト, 2008, p. 67, XI, 385) こと が主体において必要であることを指摘する，別の 言い方をすれば，過剰な驚きによって理性の使用 が妨げられることに対しては，情念の対象となる 諸事物に対して「考察する訓練 s'exercer en la considération」（デカルト, 2008, p. 67, XI, 385) が必要とされる.そしてこの理性による過剰な驚 きの統御が主体における身体運動の改変に関係づ けられる，なぜなら，理性によって情念を統御す ることの結果として, 主体の身体運動にも变化が 生じるからである.デカルトは以上で議論してき 
たこと——習性によって主体の身体運動が改変さ れること——を可能にする「原理 le principe」 （デカルト，2008, p. 113, XI, 428）として, 次の ことを改めて指摘している.

心身の結びつきの特性 liaison entre notre âme et notre corps は, ひとたびある身体運動とある 思考を結びつけると，そのあとは，両者のいずれ かがわたしたちに現れれば必ずもう一方も現れる ということ，そしてまた，必ずしも同じ行動が同 じ思考にいつも結びついているわけではないこと だ.…この問題に関して，各人が自己や他人のな かに認めうる特殊なものすべてを説明するには， この原理だけで十分である（デカルト，2008， pp. 113-114, XI, 428).

他人とともに自らの生を営む主体一というの も, 主体の情念の発生原因として他人の介在がデ カルトによって指摘されているのだから—に は，任意の身体運動を改変言うなら習得すること の可能性が「習性」によって保証されている。な ぜなら，これまでの議論から，習性が身体運動の 改変に関与することが明らかだからである。この ような議論を踏まえるならば, 当の原理はデカル 卜哲学においていわば〈身体教育〉を可能にする ことの原理と表現することもできる，なぜなら， デカルト哲学に扮いて主体の身体運動が改变され る文脈を検討するならば，まさにこの原理を基と して議論がなされるからである、ただし，このよ うな習性とは，先に指摘した「身体機械」の適用 される範囲においての久認められる注22)。すなわ ち先行研究によれば，習性は「特定の思考と身体 の特定の状態との対応関係であり，身体のうちに 根拠を持つ」（持田，1992, p. 106）ものであり, 「習性の個人的時間的差異の根拠も身体の状態そ のものに求められなければならない」（持田, 1992, p. 105）ものである。それゆえ単に習性と いう仕組みを示すことのみでは，諸動物に対する 調教と何ら変わらないものであるとの批判を認め ることとなる，それならば，主体における身体運 動の改変過程を示そうとするならば，諸動物にお
けるそれと論じ分けるべき点についても議論が必 要である注23). そこで主体の理性的思考や先に挙 げた訓練抢よび工夫，さらに目的的契機としての 善を考察することによって, 主体における身体運 動の習得過程が諸動物との違いのもとに見えて来 るだろう。

\section{N＼cjkstart修練と理性}

情念を理性的思考によって統御するとは，そも そもいかなることであるのか. デカルトはこの問 いに対してまず以下のように言及する.

わたしたちの情念も, 意志の作用 l'action de notre volontéによって直接的に directement 引き 起こしたり取り去ったりはできない，持とうと意 志する情念に習慣的に結びついているものを表象 la représentationしたり，斥けようと意志する情 念と相容れないものを表象することで, 間接的 indirectementに，引き起こしたり取り去ったり できるのだ（デカルト，2008, pp. 42-43, XI, 362).

意志によって任意の情念をいわば直接に引き起 こすことはできず，当の情念が生まれたのちに主 体の意志によって情念の発生する仕方を間接的に 変更することの可能性が指摘されている注24). 具 体的には，「危険が大きくないとか，逃げるより も防ぐほうがつねに安全であるとか，勝てば誇り と喜びを得るだろうが逃げれば心残りと恥しか残 らないとか, そう得心させる理由, 対象, 実例を 懸命に考える s'appliquer à considérer les raisons, les objets, ou les exemples 必要がある」（デカル ト，2008，p. 43，XI，363）。ただし, 理性による 情念の統制はいつでも主体が自由に行いうるわけ ではない。なぜなら「精神はほんの小さな情念は たやすく抑えるが，きわめて激しい強大な les plus violentes et les plus fortes 情念は, 血液と精 気の興奮 l'émotion du sang et des esprits が鎮ま るまで，抑えることができない」（デカルト， 2008, p. 44, XI, 364）からである. それゆえ「こ の興奮が活性しているあいだ pendant que cette 
émotion est en sa vigueur 意志のなしうるのはせ いぜい，この興奮の及ぼす結果に同意しないne pas consentir à ses effetsで, 興奮が身体に促す 運動のいくつかを制止することde retenir plusieurs des mouvements auxquels elle dispose le corps である」（デカルト，2008，p. 44，XI， 363)注25). 端的に言えば，意志によって情念を統 制することは主体において生ずる情念のいわば強 弱に左右される，そしてこの情念の統制に抢い て，先に言及された「工夫」の実質が大きな役割 を果たすと言えるのである，具体的に言えば，以 下のような議論を展開することができる.

デカルトは理性的思考の実質として，「工夫 l'industrie」の必要性抢よび重要性を『情念論』 の諸箇所において認めている注26).たとえば彼に よれば，「意志は情念を直接に引き起こす能力を 持たない la volonté n'ayant pas le pouvoir d'exciter directement les passions」（デカルト，2008, p. 46, XI, 365）ため,「工夫を用いて次々にさま ざまのものを注視することに努める d'user d'industrie, et s'appliquer à considérer successivement diverses choses よう強いられる」（デカル ト，2008, p. 46, XI, 365-366). すなわち任意の 身体運動を行うことにおいては, 意志を通じて情 念の発生といわば向き合い, 理性と意志とを用い て任意の身体運動を発現することが主体に求めら れる. というのも, 情念の発生から身体運動が生 じる際, 理性と意志とによって情念から生じうる 身体運動に改変を試みること一一言うなら「工夫 を凝らす」こと—により, 結果として生じる主 体の身体運動にも違いが生じるからである注27). このことは,「恐怖 la peur」の情念に対する場合 のデカルトの指摘において, 明瞭に確認される.

恐怖の主要原因 la principale cause de la peur は，不意を突かれることだから，それを免れる最 良の策は, 予熟慮をこらしd'user de préméditation, 恐怖を生む不安のあるあらゆる結果に備 えること de se préparer à tous les événements, la crainte desquels la peut causer である(デカルト， 2008, p. 153, XI, 463).
さまざまな状況に対してあらかじめ熟慮をこら し, 恐怖から生まれる諸々の結果に備えることに よって, 突然に恐怖が生じた場合においても主体 は適切な行動を行いうるとデカルトは見な す注28)。これらのことを集約的に言えば，熟慮と は理性抢よび意志との協働によってなされるもの であり，そのことを通じて主体は自らに拈ける任 意の身体運動を改変することになるのである.

ところで, 上に挙げた工夫抢よび熟慮は「予備 修練 la préméditation」という言い方によってな お具体化されている.すなわち『情念論』の末尾 において，「情念はその本性上すべて善い toutes bonnes de leur nature」（デカルト，2008, p. 178, XI，485）ものと見なされ，「その悪用法や過剩を 避けるだけでよい nous n'avons rien à éviter que leurs mauvais usages ou leurs excès」(デカルト, 2008, p. 178, XI, 486) と指摘される. そしてデ カルトは情念の悪用や過剰を防ぐ治療法 les remèdes として「生来の欠陥を正しうるための 予備修練と工夫 la préméditation, et l'industrie par laquelle on peut corriger les défauts de son naturel」（デカルト, 2008, p. 178, XI, 486）を挙 げ，これは「自分のうちに抢いて血液と精気の運 動を, それがふだん結びついている思考と, 分離 していく訓練 en s'exerçant à séparer en soi les mouvements du sang et des esprits をつむことに よってできる」(デカルト，2008, p. 178, XI, 486) とされる. 別の視点から言えば, 先に言及された 習性の仕組久をも含め, 理性的思考による意識の いわば「改革」を図ることで主体に生ずる情念も 変化し, その結果として身体運動もまた改変され る注29). 先に述べたように理性と意志とにもとづ く工夫抢よび熟慮—つまり予備修練——の反復 により, 主体の身体運動が改変されるからであ る.さらに『情念論』第二部第144項から146項 に扔いて述べられるように, 理性的思考による情 念の改変は, 主体が自らの得られる善に対しての 及欲望を仕向けるために行われる注30).すなわち 「わたしたちの欲望の大部分は，まったくわたし たちだけに依存するのでもなければ，まったく他 に依存するのでもない，そうした事物にまで及ん 
でいる la plupart de nos désirs s'étendent à des choses qui ne dépendent pas toutes de nous, ni toutes d'autrui から，これらのものにおいて，わ たしたちにのみ依存する部分を正確に区別 distinguer すべきである」（デカルト，2008，p. 125， XI, 439). そしてこの欲望の対象のうちでも「わ たしたちにのみ依存する部分」を通じて善を得る ことにより，「精神の快い情動 une agréable émotion de l'âme」(デカルト，2008, p. 79, XI, 396) としての「喜び la joie」（デカルト， 2008, p. 79, XI，396）が当の主体にもたらされる．というの も，この「喜び la joie」とはそれによって「精神 による善の享受 la jouissance」（デカルト，2008, p. 79，XI，396）を成り立たせるものだからであ る・結論的に言えば，欲望の情念を契機として 「善」を欲することに打いて，習性—この仕組 みには驚きの情念の意義も含まれるべきである ——と理性および意志とを伴う熟慮としての予備 修練によって情念を統御し, 獲得可能な善へ向け て主体は自らの身体運動を改変する，他方で主体 が身体運動を改変するその目的とは注31)，善を得 たことに結果する精神の快い情動，つまり「喜び」 を享受することにあったのである。

\section{$\mathrm{V}$ 結論：}

\section{身体運動における「情念」の位置}

本稿の議論から得られた結果は次の通りであ る. 第 1 に，主体に打ける身体運動の発現は， 各々が生得的に有する情念と心的因果性とを通じ て密接に関係して抢り，とりわけ「善」を求めて 身体と諸感覚とを機敏にする欲望の情念が主体の 身体運動に深く影響していること．第 2 に，習 性という仕組みを検討することから，任意の外的 刺激とそれに対応する情念の発生との結びつきは 後天的に変化するものであり，この結果として現 れる主体の身体運動に対しても有意な影響を及ぼ すこと。さらに驚きの情念は習性との関連におい ても主体における身体運動の改変契機たりうるこ と. 第 3 に，主体は自らの理性ならびに意志を 用いた工夫，さらにその実質としての熟慮
まりは予備修練——にっても自らの身体運動を 任意に改変しうることである。これらの結果から 次のことが結論づけられる. 主体が自らの身体運 動を改変する際，一方では主体のうちに生ずる諸 情念が身体と因果的に関係するのであって，この ことは欲望や驚きの情念が主体における身体運動 の発現に影響を与えることからも明らかである. 他方で主体は自らの理性と自由意志とに基づく熟 慮言うなら予備修練を通じて任意の身体運動を発 現する．別の表現によってこれらの結論を言い直 せば，「精神は真に身体全体に結合している」（デ カルト，2008, p. 29, XI, 351）がゆえに諸情念や 理性打よび自由意志はいずれも身体と心的因果性 のもとで関係し, 習性と理性そして自由意志によ る情念の統制を経て主体は任意に身体運動を改変 する.そして主体が自らの身体運動を改変するこ との目的とは，自らに依存する善の獲得を通じて 「精神の快い情動」（デカルト，2008，p. 79，XI， 396）たる「喜び」（デカルト，2008，p. 79, XI, 396）を得ることであったのだ．本稿の議論内容 および結論は体育哲学の研究史に新たな議論の萌 芽を提供するものであり，斯界に新たな議論を起 こしうるものとなるだろう.

今後の課題としては次の 2 つのことが挙げら れる，第 1 に，他人との関係の構築過程につい ても主体に打ける情念の発生という観点からさら に検討できる．なぜなら，『情念論』第二部第 140項などの記述から注32), 情念の生じる原因と しての他人との交わりのあり方を考察することが 可能であり，そのことは情念にもとづく身体運動 の発現を検討することにおいても有益な示唆をも たらすからである、第 2 に，体育哲学の先行史 に抢いては「技術」と「技能」を論じ分けて議論 することの必要性がこのところ指摘されてい る注33)。それらの語彙が本稿の議論といかなる関 連を有しているのかについて考察されるべきだろ う。というのも，技術および技能が概念として異 なるのならば，それらの各々と情念にもとづく主 体の身体運動の発現との関係について検討できる からである。 


\section{謝辞}

貴重なご教示の数々を本誌審査員各位から賜つ た. 謹んで深謝申し上げる.

\section{付記}

本論文は平成 24 年度日本体育学会茨城支部研 究奨励金採択課題に抢けるく報告 $>$ の議論を大幅 に改め，書き下ろしたものである.

\section{注}

注 1）本稿に扔ける「身体運動」の概念が指し示す範 囲について，以下で注釈的に記して掞きたい。な ぜなら，この概念の実質の決定については慎重な 議論が要されるからである. まず本稿が意図する 「身体運動」とは，打もに主体がいわゆる社会的 生活のなかで日常的に行う挙措動作やスポーツ活 動に㧍いて発揮する運動技術など, 広範なものを 指している. 別の角度から言えば, 主体の意志に よって習得あるいは改変される「意図的」身体運 動が想定されている．ところが「身体運動」の概 念のうちには, 例えば解剖学において検討対象と されるような生理学的な側面から捉えた身体運動 —いわば「解剖学的」身体運動とでも呼びうる ようなもの——もまた, 想定可能である.つまり 「身体運動」という概念には多義性が認められる のであって, 本稿においても外的な諸対象からの 働きかけを通じて主体の身体内部における血液や 諸器官の被る影響について言及する。しかし, 周 知のように主体に抢ける「意図的」身体運動の発 現は「解剖学的」身体運動を前提とするものであ り, 後者は前者に収斂されるとも考えられる. 別 の角度から述べれば, 体育実践やスポーツ活動に おける主体の身体運動の有り様を問題にする体育 学の文脈に扮いて,「解剖学的」身体運動のみを 独立して—つまり「意図的」身体運動とは無関 係なものとして——論ずることは困難である。そ こで本稿では両者の意味合いの差異および両者の 関係一「解剖学的」身体運動も「意図的」身体 運動の発現に集約される, いわば包摂的な関係 —にも留意しつつ, 主体による「意図的」身体 運動の改変を主たる研究対象として議論を展開す る.

注 2) 主体の身体運動について扱った研究は, 体育学 において著名な部類のものを瞥見するだけでも以 下のものが直ちに想起されるまず金子（2005）
に抢いては, いわゆる「身体知」の観点から身体 運動の構造について検討されている.また Meinel und Schnabel (1977) の議論では, 「動作 コオーディネーション Bewegungskoordination」 といった一連の身体運動を局面に分けて検討し， 主体に抢ける身体運動の習得に活かす議論が行わ れている、またこれらとは別に, 体育哲学分野の 先行史では瀧澤 (2011) が現象学の立場および運 動の基本的な構成要素とされる下位〔動作〕の視 点から主体の身体運動について議論している.さ らにLaban（1980）の議論では, ダンスおよびリ ズム運動の視座から身体運動の習得過程が考察さ れている.あるいはLatchaw and Egstrom (1969) の議論では「力 Strength」や「持久力 Endurance」, そして「柔軟性 Flexibility」など身 体運動において見られる諸性質に着目することか ら主体における身体運動の改変につながる考察が 行われた. 総じてこれらの議論においてはそれぞ れに独自の研究成果が挙げられているものの, 本 稿が主題的に論ずる主体の情念や心身関係のあり 方については顕著に取り上げられてはいない。

注 3）ただし Lawther（1968）の議論に抢いて，「意 欲 Motivation」と「情動 Emotion」, そして「ス トレスStress」の各視点から心的な部分が主体の 身体運動に影響を及ぼすことへの言及が見られ る. しかし, 当該の研究は心的な諸要素の身体に 及ぼす影響が概括的に述べられるに留まってお り, 本稿はこの問題提起をさらに深める研究史的 な立場を採る。

注 4) 近年の体育哲学分野に扔いては, 林 (2011) が デカルトの心身論を再考する議論を展開した，具 体的には, 体育原理分野一2005年度を以て「体 育哲学分野」と改称される以前の分野名の呼称 ——でこれまで蓄積されてきた心身関係論を批判 的に検討しつつ, デカルトの心身観が「心身二元 論」に限られるものではないことを指摘している.

注 5) 木庭（2000）によれば, プラトンの身体論につ づいてデカルトの身体論, とりわけ『情念論』が 検討の対象とされることの意義について次のよう な指摘を確認できる.「『情念論』にみられる心身 の複合的な捉え方は, 通俗的なデカルト解釈では 決して気づかれることない, 現実の人間理解に必 要不可欠な視点を提示している」(木庭, 2000, p. 59).また林（2012）は「習性」の体育学的応用 へ向けた可能性を指摘している.

注 6) 使用するデカルトの原典テキストは Adam, C. et Tannery, P. (1996) によるものを使用し, 巻数 
をアルファベットで，頁数をアラビア数字でそれ ぞれ示す。なお邦訳テキストは現在までわが国で 刊行されているものを用いるが，原典テキストの 趣旨を変えない程度に訳出の統一ならびに語句の 変更を施した箇所がある。

注 7）「情念」という呼称については, 本稿の冒頭で 述べたように「感情」という言い方もできるかも しれない，デカルトが『情念論』のなかで取り上 げる諸情念については, 現在では「感情」に相当 するものと考えられるからである. またデカルト 研究者のうちでも, 桂 (1982) のように『情念論』 を『感情論』（桂, 1982, p. 145）と表記する論者 も見られる. 本稿では慣例にしたがって情念およ び『情念論』という呼称で表記を統一する.

注 8） デカルトの見解は, 従来の体育原理分野におい て散見された〈心身一如〉という心身観とは異な るものである。なぜなら, 従来の体育における心 身関係論では心身各々を実体と見なす立場はほと んぞ見られないのに対して，デカルトは心身を実 体として認めた上，双方の不可分に合一したもの が主体に拈ける心身のあり方であると見なすから である. 彼のこのような立場がはっきりと示され たのは「実体の合一」が示されたテキスト，つま り『省察』「第六省察」ならびにその続編である 『省察』「反論と答弁」における「第四答弁」にお いてである。とりわけ後者においては，「精神は 身体と実体的に合一している esse corpori substantialiter unitam」（デカルト，2001a， p. 277, VII，228）と述べられている. なおデカルトの心 身観が体育学で検討対象とされる主体にも適用さ れうるかという問いについては議論されるべきこ とである——なぜなら, デカルトの心身観を根拠 づける「神」の概念を体育学においていかに論ず べきであるのかという議論がまだ収束していない のだから——か，林（2011）の議論ではこの問い に対する一見解が示されている.なお体育原理分 野における心身一如という心身観への批判につい ては，すでに佐藤（2003）によって充足的に検討 が果たされている，その要諦とは，「心身を一体 のものとする体育的心身関係論は, 論理的に検討 してみると, 体育論者の思惑とはむしろ逆に, 体 育の成立根拠を提示するよりも，体育そのものの 必要性を否定してしまうような結果を導いてしま う」（佐藤，2003， p. 193）ものであった.

注 9）この箇所においてデカルトが言及する心身関係 とは，心身の直接的な関係としての「心的因果性」 と呼ばれるものである（小林, 2009, p. 156).
具体的には「合一 union」（デカルト， 2001c, p. 18, III， 665）という「原初的概念 notions primitives」（デカルト，2001c, p. 18, III, 665）によっ てデカルトが示すように，心的因果性とは主体が 実際に知性と意志とによって自らの身体を動かす ことから心身の直接的な相関が認識されるもので あって, 物理的言うなら数学的な論証によってそ の実質が明らかにされるものではない。それゆえ 心的因果性とは物理的な事物の因果関係としての 相互作用説一「一方で身体があり，他方に精神 があって，それぞれがそれぞれの身分を保持しつ つ，打互いに作用するということ（安孫子ほか編, 2013, p. 278）—とは異なるものである.なぜ なら，原初的概念としての「合一」とはそれ以上 分析することができず，物質ではない精神と物質 としての身体のあいだの因果性はこの「原初的概 念」それ自体を以て一一物理的な因果関係とはい わば別次元の問題として——理解されるものだか らである.な抢「心的因果性」の議論としての妥 当性については，1648年および1649年に交わさ れたデカルトとモア (Henry More. 1614-1687) との往復書簡に掞いて「魂と神，そして精神の拡 がりについての問い la question de l'extension de l'âme, de Dieu, et des esprits」(Bitbol-Hespériès, 1991, p. 152）としても顕在化するが，デカルト がこの「心的因果性」の立場を変更しなかったこ とは周知のと拈りである.

注10）この箇所の「放射している」という表現には議 論も予想される.なぜなら, 物理的なものではな い精神が「放射している」とはいかなることであ るのかという問いの提起が可能だからである.こ の問いについて現在わが国で公刊されている『情 念論』の邦訳のうち, 野田（1999）による『情念 論』第一部第34項の訳出では, 当該箇所が「作用 をおよぼす」と訳される（デカルト，1999, p. 121).このことを敷衍すれば, 心身の作用が身体 における任意の局所にのみ実効するものではな く,むしろ身体の総体にわたって行われているも のと解积されよう.

注11） デカルトが情念を「精神の受動 passions」（デ カルト, 2008, p. 20, XI, 342) と位置づけている にもかかわらず，この言及ではあたかも情念が身 体に対して「能動的」に働きかけているようにも 解釈できる．この問題に対しては, 『情念論』第 一部第 1 項から第 2 項にかけてのデカルトの言及 を参照したい。この第 1 項および第 2 項に抢い て，彼は以下のように述べている.「新たに生起 
することすべては，一般に哲学者たちによって， それが生じる主体に関しては「受動 une passion」 とよばれ，それを生じさせる主体に関しては「能 動 une action」とよばれる.したがって，能動者 と受動者 l'agent et le patientはたいていひどく異 なるにもかかわらず，それでもやはり，能動と受 動は, つねに同一のもの l'action et la passion ne laissent pas d'être toujours une même chose であ り，2つの違った主体に関係づけうることで，能 動と受動という $2 つ 0$ 名をもつ。・精神が結合し ている身体以上に，わたしたちの精神に対して直 接に作用する主体があるとは認められない。した がって，精神に拈いて「受動 une passion」であ るものは，一般に身体において「能動 une action」 である，と考えねばならない」(デカルト，2008， p. 5-6, XI, 328). この言及について中村（1997） の注解によれば，能動と受動が同一の事象の 2 つ の側面を指すものとされる，さらにデカルトの言 及に解釈を加えると, なるほど情念は身体をはじ めとする外的な諸対象から作用を受けることで生 じるという意味に抏いて「受動」である。しかし 同じ事象を身体の側から捉え直すならば，情念の 働きかけによって主体における身体運動が発現す ることも明らかである。すなわち，この後者の意 味に㧧いて情念は「能動」と理解することができ るため, デカルトは「能動と受動は，つねに同一 のもの une même chose」（デカルト，2008, p. 6, XI，328）と指摘したのであろう. 総括的に言え ば，なるほど情念が「受動」であることは疑いえ ないにせよ，見方によっては「能動」としても情 念を捉え直すことができるのである.

注12）松果腺とは, 現代医学においては, たとえばシ ェフラー・シュミット（2002）が示すように, 「松果体 pineal body」(シェフラー・シュミット, 2002, p. 184）に相当するものである. なるほど デカルトの考える松果腺と現代の松果体とでは, その機能抢よび位置づけが異なると考えてよい. しかし，デカルトの想定した松果腺ないしは心身 結合のいわばモデルが現代的な意義を有している ことは, 中村 (2007) の指摘—「…現代の生理 学や生化学の発達そのもののなかで, まったく別 なところから新しい展望が開けてきた。松果体が なんと人体の内分泌腺の 1 つとして，またそれと のつながりで，生体リズムを司る生物時計にかか わるものとして，新しく見直されるようになった のである」(中村, 2007, p. 260) 一一加え，小 林（2009）の指摘一「現代でも, 一方で脳科学
を推し進め, 他方で心的存在は否定せず，その物 理的基盤を脳に求めるとするならば，そのあいだ の関係を説明しようとする場合，この松果腺仮説 を訂正・洗練させた形態の仮説を提示するほかは ないと考えられる」(小林，2009, p. 102）—— らも明らかである。

注13）動物精気が身体運動の生理的な根拠であること については，たとえば『情念論』第一部第11項に おける筋肉 des muscles の運動を述べたデカルト の次の言及からも明らかであろう。「精気が出て いく方の筋肉が伸びて弛む. 精気が入った方の筋 肉は急速に精気をはらんで収縮し, その付着する 肢体を引っ張る」（デカルト， 2008, p. 14, XI, 335 -336). ところで動物精気は現代の医学による知 見においては存在しないものである.しかし，デ カルトが現代医学をはじめとした自然科学に抢け る思想的な枠組みを整えたという点において—— さらには事物の数理的説明としてのエヴィデン ス・ベース evidence base の哲学的基礎を明らか にしたという観点に拈いて—，個々の事実的な 知見の正誤は問題とはならないであろう.

注14）主体に拈ける情念の対象は, 人間としてのく他 人〉にのみ限られるわけではない。なぜなら，デ カルトは主体における情念の発生対象として, 必 ずしも人格としての他者一つまり〈他人〉に限定して議論を展開しているわけではないから である.しかしデカルトは人格としての他人を 『情念論』第三部第162項において「自由原因les causes libres」（デカルト, 2008, p. 143, XI, 454) ——善悪のいずれをなすかはわからないが，わ たしたちに善または悪をなしうると判断される nous jugeons capable de nous faire du bien ou du mal, sans que nous sachions lequel des deux elles feront」もの一として捉え, 自由原因としての 他人を検討の対象として情念を論じている.すな わち同じ第三部第162項において，「善だけが期待 される自由原因に対しては, 単なる崇敬 une simple vénération よりも愛と献身 l'amour et de la dévotionの気持ちを持つのであり, 悪だけが期待さ れる自由原因に対しては, 憎しみ la haine を抱く し，またここの善や悪の原因が自由 libreだと判 断されるのでなければ，わたしたちは，その好意

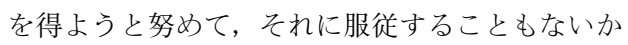
ら」（デカルト, 2008, p. 143-144, XI, 454）など と語られる。それゆえ, てわゆる対人関係の文脈 においてデカルトの議論を検討するに際し, 情念 の対象を「他者」というよりは〈他人〉と表現す 
ることによってもデカルトの意図に即して議論す ることは可能である.

注15）議論のこの箇所において，なぜ「とりわけ」と 注釈的な表現を用いなければならないのか。その 答えは，主体における身体運動に影響を及ぼす情 念が必ずしも「欲望」と「驚き」の 2 つに限られ るものではないことが指摘できるからである。す なわち, 『情念論』第二部第141項において欲望, 喜び，悲しみの各情念における主体の身体運動に 対する影響について考察のなされた後, デカルト は次のように言及する。「‥これらの情念にとも なう身体運動 les mouvements corporels は，あま り激しい violents と，すべて健康に有害になりう る être nuisibles à la santé し，反対に，ただ啇度 modères である場合に, 健康に有用 utiles であり うる」(デカルト，2008, p. 120, XI, 434).この言 及から了解されるように，「喜び」および「悲し み」の情念もまた，主体の身体運動に影響を及ぼ すことは確認される。しかしながら，主体の身体 運動とのかかわりにおいて『情念論』では「欲望」 や「驚き」の情念が「喜び」や「悲しみ」のそれ に比べて詳細な考察のなしうるほどに多く言及さ れている。それゆえ本稿では「欲望」と「驚き」 の情念を議論におけるいわば選択的な着眼として 考察を展開した。な打喜び」と「悲しみ」が身 体運動に及ぼす影響については，デカルトが指摘 するように，いわば健康論を視野に含めた議論に おいて検討されるべきであろうが，今後の課題と して指摘するに留めたい.

注16）「行為の実現のためには時間と身体行為に結び つく「欲望」の情念が必須なのである」（小林， 1995，傍点小林，p. 454）。 な扢この言及に打け る「行為」ならびに「身体行為」とは, 本脚注が 挿入された文脈で述べられている主体の身体運動 と同義である. 本稿も小林の解釈に準じ，欲望の 身体運動に対する影響について『情念論』第二部 第101項へ言及する—小林も自らの議論におい てこの項を参照する一からである.

注17）この「善 un bien」（デカルト，2008, p. 57, XI, 375）の意味内容として何を考えればよいかとい う問いについては，別途に議論されるべきことで あろう。なぜなら，『情念論』においては身体運 動と善との関係について踏み込んだ言及が行われ ていないからである. デカルトのテキストからこ の善に該当するものを身体教育の視点を以て探す ならば，1645年10月 6 日付けエリザベト宛て書 簡において確認される「身体の完全性 perfection $\mathrm{du}$ cors」（デカルト，2001c, p. 144, IV, 309）が 1 つの候補として考えられる，というのも，身体を 動かすこと—つまり主体による「意図的な」身 体運動—と善との関連を探るとすれば，「身体 の完全性 perfection du corps」が文脈上に抢ける 候補の 1 つとて考えられるからである.ただ し，このことの詳細な論証については別途の課題 としたい. なお中村（2012）によれば，この「身 体の完全性」の現れる文脈がデカルトにおける 「一種のスポーツ論」（中村, 2012, p. 166）とみ なされて抢り，デカルトが「身体の完全性」につ いて述べるテキストは,「スポーツ哲学」の議論 としても取り上げられよう。ただし中村が自らの 議論において引用した竹田篤司ほか訳（2001）に おいて，「スポーツ」（デカルト，2001b，p. 343, IV，309）と訳出された語の原文は“des exercices du corps”であり, この仏語が「スポーツ」とし て訳出されることの妥当性は改めて議論しなけれ ばならない。なぜなら原典の語句に忠実な訳出を 志向するならば，当該の仏語原文は「身体（の） 修練」とも訳出されうるものであって,「スポー ツ」の概念に「身体（の）修練」という含意が含 まれるか否かについては別途に議論される必要が あるからである。

注18） デカルト哲学の形成期ともいえる1630年 3 月 18日付けメルセン又宛て書簡において, 以下の言 及が確認される。「ある人々を踊り出したくなる 気持ちにさせる同じもの la même chose qui fait envie de danser à quelques-uns が，他の人々を泣 きたくなる気持ちにさせうる」（デカルト，2012, p. 126, I，133). デカルトによれば，その原因は 「われわれの記憶の中にある観念が刺激されるこ とにのみ由来する cela ne vient que de ce que les idées qui sont en notre mémoire sont excitées」 (デカルト，2012，p. 126, I，133-134）からであ る. その直後デカルトは次のように述べている. 「以前ある旋律が奏でられているときに踊りを楽 しんだ者は，同じような旋律を聞くとすぐにもう 一度踊りたくなる ceux qui ont pris autrefois plaisir à danser lors qu' on jouait un certain air, sitôt qu' ils en entendent de semblable, l'envie de danser leur revientものです. 反対に，もしだれ かがガヤルド des gaillardes（引用者注：訳者に よれば「三拍子で速いリズムの舞曲」のこと）が 奏でられているのを聞くたびに何か悲しい思いを したとすれば，別の時にそれを聞けば間違いなく infailliblement 悲しくなることでしょう。このこ 
とはまったく確かであるので，バイオリンの音を 聞かせながら犬を五，六回むち打ったなら，犬は 別のときにその楽音を聞くとすぐに吠えて逃げ出 すだろう，と私は判断します」（デカルト， 2012， p. 126, I, 134). Lodis=Lewis（1998）はこの箇 所への注解において, この記述と習性の事例が述 べられた『情念論』第一部第50項における記述と の関連を指摘一ただし，人間においては「その 機構についての理解のゆえに grâce à la compréhension du mécanisme $\rfloor$ (Lodis $=$ Lewis, 1998, p. 72)，この仕組みに隷従されえないとする一しし ている，つまり，後天的な働きかけによって任意 の刺激とそれに対する反応を変更することが可能 となる. それゆえ楽器の音に合わせて犬を打つな らば，これ以後同じ楽器の演奏が行われた際に犬 は打たれることを予期して逃げ出すことになる. この事例では楽器の音色と犬を殴打することにつ いて直接的な関係は無いといえる.にもかかわら ず，心身の対応関係ゆえにこの結びつきが人間や 動物の行動を規定する。この対応に関して三輪 （1985）によれば，この仕組みはいわゆる「パヴ ロフの犬」のしくみになぞらえることが可能であ るとする．デカルトが述べた「習性」と「パヴロ フの犬」とのあいだの厳密な同定については議論 もあろうが, 類似の作用が確認されることには留 意すべきである。

注19）当該の項では以下のように言及される。「たた したちが言葉を話すとき，言おうとすることの意 味だけを考えるが，このほうが，同じ言葉を出す のに要する舌や唇のあらゆる動かし方を考えるよ りも，はるかに敏速にうまく，舌や唇を動かすこ とになる。わたしたちが話すことを学んで獲得し た習性 l'habitude que nous avons acquise en apprenant à parlerによって，腺を介して舌や唇を 動かしうる精神の働きを，わたしたちは舌や唇の 運動そのものにでなく，その運動から生じる言葉 の意味に結びつけたからだ」（デカルト，2008, p. $42, \mathrm{XI}, 362)$.

注20）『情念論』によれば，脳内の松果腺に視神経か ら伝わった外的な事物の映像が映されることで, 精神に特定の情念が呼び起こされる.『情念論』 第一部第36項によれば，或る形象—つまり任意 の外的な対象一について，「かつて身体に有害 だったもの les choses qui ont été auparavant nuisibles au corps と大いに関係がある場合，精神のな かに不安の情念，ついで大胆の情念，あるいは恐 怖や激しい怖れの情念が引き起こされる cela ex- cite en l'âme la passion de la crainte, et en suite celle de la hardiesse, ou bien celle de la peur et de l'épouvante」（デカルト, 2008, p. 36, XI, 356). デカルトによれば, 情念の発生のちがいは個々人 の「体質の違いや精神の力 le divers tempérament du corps, ou la force de l'âme」（デカルト, 2008, p. 36, XI, 356) に左右され, 同一の対象を見た際 にあらゆる人間において同じ情念が生じるわけで はない，すなわち，動物精気の流れにもとづく情 念の発生は「有害なものに対してかつて防御によ って par la défense 身を守ったか，逃走によって par la suite 身を守ったかにもよる」（デカルト， 2008, p. 36, XI, 356). その結果, 身体運動の発現 にも違いが現れることになろう.なぜなら, 主体 に拈ける身体運動は精気の流れから生じるものだ からである.このことに関して Alquié (2010) によれば，この箇所については主体の「過去の影 響 l'influence du passé」(Alquié, 2010, p. 981) が 考慮されるべき要因とされる。 また Sutton （2000）によれば，「われわれの身体が文化的な諸 形態を維持する our bodies thus hold cultural forms」（Sutton, 2000, p. 713）として，任意の身 体運動が後天的な作用によって習得される可能性 に言及している。ささらに Morgan（1994）によれ ば，「これまでの経験 previous experience」 （Morgan, 1994, p. 163）が情念の発生に影響を与 えるとの指摘が見られる. いずれにせよ，身体運 動の改変においては情念の発生がその要因となる.

注21）すでに林（2012）が指摘したように，小泉 （2007）の議論ではヤマウズラおよび食物摂取の 事例について，これらの事例が第三者による規 律・訓練の例に近いと指摘される.すなわちヤマ ウズラや食物摂取の事例は, いわば後天的な身体 運動の改変可能性を示唆するものであろう。

注22）谷川（1995）は，1646年11月23日付けニュー キャッスル候宛て書簡（IV，573）におけるデカ ルトの言及をふまえ,「習性」がデカルトにおい ては専ら身体的・機械論的に説明される旨を指摘 する。

注23）池辺（1988）によれば，「情念支配の核心」（池 辺，1988, p. 189）のために必要とされるのは 「意志による方法と習慣による方法の統合」(池辺, 1988, p. 189）であるとする.そして彼は，単に習 慣を利用するだけでは匹夫に等しいものと指摘す る. 機械論的な仕組みに留まる習慣一つまり習 性一一みならず，自由意志を併用することが身 体運動の改変に必要であるとの解釈ができるだろ 
う.

注24）情念を統御するための方法をデカルトは書簡や 著作のうちに複数記している.たとえば「過度の 情念に対する救治策 les remr̀des contre les excès des passions」(デカルト, 2001c, p. 188, IV, 411) として,「実際に起こってくるものよりも，さら に困ったことを一般的に想像し，それに耐える準 備をして抢くことで十分 c'est assez d'en avoir imaginé en général de plus fâcheux que ne sont ceux qui arrivent, et de s'être préparé à les souffrir $\lrcorner$ （デカルト，2001c, p. 188, IV, 411）である. 後述 のように，身体運動の原因としての諸情念を理性 によって制し，自らの思考によって情念を統制す ることが必要とされる.

注25）この具体例として, デカルトは以下のことを挙 げている。「たとえば，怒り la colèreが，殴る手 la main pour frapper を振りあげさせるとき, 意志 はふつうこの手を制止することができる．また恐 怖の情念が，脚を逃げるようにさせるとき，意志 は脚をとどめることができる，など」(デカルト， 2008, p. 44, XI, 364)．末尾の「など」からもうか がえるように，情念と身体運動とのこのような関 係は，主体が発現するさまざまな身体運動におい ても適用されうるものであろう。

注26）Sutton（2000）によれば，この「工夫」に対応 する語 “industrie” は英語 “artifice” と解釈する ことが可能であるとする．この語は邦語における 「技術」や「技巧」，「考案」ないしは「手管」さ らに「術策」や「策略」などの意味を有しており， 人間における理性的思考の反映がうかがわれる.

注27）このことは既にロディス＝レヴィス（1990）が 指摘している，彼女によれば，工夫とは「退けた い情念に正面から立ち向かうことができない時 に，まず，消滅させるべき情念と反対の情念を強 めるような，新たな連合を喚起することによっ て，間接的に立ち向かう，ということに存する」 （ロディス＝レヴィス，1990,p. 424）ものである.

注28）この「恐怖」の情念への対処についてのデカル トの言及は，先に『情念論』第二部第76項で示さ れた「過㮃に驚くことを控えるための治療法 remède pour s'empêcher d'admirer avec excès $」$ （デカルト，2008, p. 67, XI, 385）と関連する.と いうのも，主体に打ける身体運動の改変に理性的 思考が必要であることをデカルトがいわば一貫し て言及しているからである。

注29）この文脈に抢けるデカルトの言及には，主体が 理性的思考を発揮することへの要求が顕著に見ら
れる，例えばある情念が任意の行動をすすめる 際「その実行がいくらか遅れてもよいときl'exécution souffre quelque délai」(デカルト, 2008, p. 179，XI，487）であれば，「即座に判断をくだすの を差し控え，時間と静止 le temps et le reposによ って血液中の動摇が完全に鎮められるまで他のこ とを考えて気を紛らわさねばならないse divertir par d'autres pensées」（デカルト, 2008, p. 180, XI，487）と彼は述べている. 他方，「自分の行動 について反省する習わしをもつ人たち ceux qui sont accoutumes à faire réflexion sur leurs actions」（デカルト，2008, p. 180, XI, 487) であ れば，不意の攻撃を受けて恐怖にとらわれたと感 じる場合，「逃走するより抵抗するほうにはるか に大きな安全と名誉があることの理由を思い浮か べて en se représentant les raisons pour lesquelles il y a beaucoup plus de sûreté et plus d'honneur, 自分の思考を危険についての考慮から逸らせるよ う努める ils tacheront à détourner leur pensée de la considération du danger」(デカルト, 2008, p. 180，XI，487）ことが可能であるとデカルトは捉 えている。つまり理性によって情念を統御し, 各 々が思考に㧈ける工夫を重ねることで身体運動に 改変を図ることができる，な拉Voss（1989）に よる注解では, このような予備修練は「身体運動 と思考とのあいだのつながりを改変する先見ない しは技術 forethought and skill at altering the connection between bodily movements and thoughts」 （Voss, 1989, p. 133） と指摘しうるものである. さらに「長期にわたる準備 long-term preparation」 （Voss，1989，p. 133）と彼が指摘するように，継 続的かつ反復的な働きかけが主体に求められる. さらに Freierson（2002）によれば，主体が理性 を用いることの目的は「情念の矯正 correction」 (Freierson, 2002, p. 321)であるとする.つまり， 情念の変更それ自体が目的となるのではなく，何 らかの目的のための手段として情念の変更が行わ れるとの解釈ができる．この課題に対して本稿で は, 善という目的的契機の下に情念㧍よび身体運 動の変更がなされるものと捉える，なぜなら，理 性的思考によって欲望を統御することの背景に は, 後述するように獲得可能な善に対しての及欲 望を向けるべきであるというデカルトの見解が存 するからである。

注30）善を求める「欲望」の情念を統御することにつ いては, デカルトから以下のことが指摘されてい る。すなわち，獲得できる善を欲するにしても 
「欲望すべきものの善さをじゅうぶん明晰に認識 して，それを注意深く考察する considérer avec attentionよう努める」（デカルト，2008，p. 123， XI，437）ことが指摘されている. つまり欲求の 対象を見定める場合においても，主体は理性を用 いて対象の認識に努めることが必要となる。そし て, 前注でも述べたように, 獲得可能な善にだけ 対象を定めるべきであることをデカルトは述べて いる. 理性と意志とによる判断もまた，身体運動 の発現に影響しているのである.

注31）身体を教育することの「目的 la fin」であって, 「目標 le but」と表現されないのはなぜか。この 問いについてはデカルトによる直接的な言及が見 られないため, 断定的な回答を与えることには慎 重さが求められる. しかし, 以下に引用する考証 学的な視点から検討するならば，「目的」と表現 する方がより一層デカルトの意図を精確に示して いると考えられる.すなわちデカルトの生きた 17 世紀の仏語用法を収めた古仏語辞典の Furetière (1970）に拈いて，「目標BUT」は「通路や壁に おいて, 到着するべきところに記された点 Point marqué dans une allée, dans un mur, où on se supposer d'arriver …」具体的な事例を以て記され るのに対し, 同じ Furetière et al. (2013)におけ る「目的 FIN」では端的に「端Bout」や「末端 extrémité」, さらに例文では「あらゆる事柄の終 わりのもの ce qui termine toutes choses」や他の 用例において「神には始まりも終わりもない Dieu est sans commencement, et sans fin」など 「目標 BUT」に比べて「目的 FIN」の語には理念 的ないし抽象的な含意を強く読み取ることができ る.つまり「目標」と「目的」はこの順で「具体」 と「抽象」という対比に烼いて捉えうるものであ る.ところで以上の区別を踏まえるに, デカルト の『情念論』に拈ける「善」は未だ抽象的ないし は理念的なものに留まっており，具体的な実質を 指し示すには至ってはいない，それゆえ『情念論』 に考察範囲を限るなら, 主体が「善」を得ること は「目的」であって，「目標」ではないとひとま ずにせよ結論づけられるのではないか. なおデカ ルトが「目標 le but」と「目的 la fin」を使い分 けることで議論を展開した箇所は 1645 年 8 月 18 日付けエリザベト宛書簡に㧍いて確認されるもの の, 訳出に議論の生じうる状況であることやデカ ルトの道徳論の全体を踏まえて議論することが求 められる—当該書簡についての議論は後の 1647 年11月 20 日付け書簡（デカルト，2001b， p. 414-
418，V，81-86）および『情念論』第三部第153項 における「高邁 la générosité」（デカルト，2008， p. 134, XI，445）など広範なテキスト読解を前提 とすることがデカルト道徳論の研究史から明らか である——、そのため, 本稿ではデカルトにおけ る「目標」と「目的」の概念の差異については以 降の議論されるべき課題として指摘するにとどめ たい.

注32）「憎しみについてDe la Haine」（デカルト， 2008, p. 118-119, XI, 433）と題された『情念論』 第二部第140項では, 他人との「交わり conservation」（デカルト, 2008, p. 119, XI, 433）のなか で主体に生ずる情念の有り様が検討されている. とりわけ「実在的主体 sujet réel」（デカルト, 2008, p. 118, XI, 433）として他人を位置付けるこ の文脈は一七とうのは, 実在的主体とはそのう ちに「悪 le mal」（デカルト, 2008, p. 118, XI, 433) や「善 bien」（デカルト, 2008, p. 119, XI, 433）を含有するものとして見なされており，こ れを人間としての〈他人〉と想定することも可能 だか—，「ある人の不品行からわたしたちを 遠ざける憎しみ la haine qui nous èloigne des mauvais mœurs de quelqu'un」(デカルト, 2008, p. 118, XI，433）と悲しみの情念, さらにはそれら の情念と主体が有する善との関係について詳細に 論じられている.すなわちデカルトによるこれら の言及は, 今後主体における身体運動の発現ある いは教育の観点からデカルト哲学を捉え直す際に 示唆の提供が期待される. 情念の発生および教育 をめぐる諸問題において,「実在的主体」として の〈他人〉の存在が論点のうちの 1 つとなりうる からである。

注33）身体運動における「技術」と「技能」の概念を 論じ分けることの必要性については，久保 (2010) の議論に打いて確認可能である.すなわち「「技 術」は客観的な学習の内容であり,「技能」は主 観的な能力化された状態ということができる.つ まり，「技術」は学習者の「学習の内容」であり, それに対して「技能」は, 学習者の身に付いた 「技術の能力」である.よって, 同じ「技術」の 習得を目指しながら, 最終的には同じ「技能」を 持たないということになる」（久保, 2010, p. 132).久保によれば, 当該の観点において両者の 差異が確認されるものとする. 


\section{文献}

安孫子信 ·出口康夫・松田克進編（2013）デカルトを めぐる論戦. 京都大学学術出版会: 京都, p. 278.

Adam, C. et Tannery, P. (Eds.) (1996) OEuvres de Descartes (11vols). J. Vrin: Paris.

Alquié, F. (Ed.) (2010) OEuvres philosophiques (Tom. 3, 1643-1650). Garnier: Paris, p. 981.

Bitbol-Hespériès, A. (1991) Le dualisme dans la correspondance entre Henry More et Descartes. In: Vieillard-Baron, J.-L. (Ed.), Autour de Descartes Le dualisme de l'âme et du corps. Vrin: Paris, pp. 152.

デカルト : Voss, S. (trans.) (1989) The passions of the soul. Hackett Publishing Company: Indianapolis and Cambridge, p. 133.

デカルト：野田又夫訳 (1999) 情念論. 中央公論新社 :

東京, p. 121.

デカルト : 所雄章ほか訳 (2001a) 増補版デカルト著作

集 (第二巻). 白水社 : 東京, p. 277 .

デカルト：竹田篤司ほか訳（2001b）増補版デカルト著

作集 (第三巻). 白水社 : 東京, pp. 343, 387-388, 414-418.

デカルト：山田弘明訳 (2001c) デカルト＝エリザベト 往復書簡. 講談社 : 東京, pp. 18, 144, 185, 188.

デカルト：谷川多佳子訳（2008）情念論. 岩波書店 :

東京, pp. 5-6, 14, 20-21, 25, 27-30, 33, 36, 39, 42$44,46,49,50,52-53,55,57,60-62,65-68,75,79,86$, $94,113-114,116-120,123,125,134,143-144,153$, 178-180, 188.

デカルト：小林道夫訳 (2009) アルノ一宛書簡 1648

年 7 月 29 日. 中央公論新社 : 東京, p. 103.

デカルト：山田弘明ほか訳（2012）デカルト全書簡集 (第一巻). 知泉書館 : 東京, p. 126.

Freierson, P.R. (2002) Learning to love: From Egoism to Generosity in Descartes. Journal of the History of Philosophy, 40 (3): 313-338.

Furetière, A. (1970) Dictionnaire universel, contenant généralement tous les mots français Tome 1. Slatkine Reprints: Genève.

Furetiére, A., Leers, A. et R. (2013) Dictionnaire universel, contenant généralement tous les mots françois (Éd. 1701) Tome 2. Hachette Livre BNF: Paris.

林 洋輔（2011）体育哲学におけるデカルト心身論の 原理論的考究 : 従来のデカルト心身論批判の再検討 を通して。体育学研究，56(2)：271-286.

林 洋輔（2012）体育哲学における身体 corps の二面
性：デカルト哲学における「人間」理解を手がかり

として. 身体運動文化研究， 17(1)：43-65.

池辺義教 (1988) デカルトの誤謬論. 行路社 : 京都, p. 189.

金子明友 (2005) 身体知の形成 : 運動分析論講義, 上. 明和出版 : 東京.

桂 寿一 (1982) デカルト哲学とその発展（復刊第 2

刷). 東京大学出版会 : 東京, p. 145.

木庭康樹（2000）プラトンに拈り認識問題としての 身体. 体育原理研究, 30: 59-68.

小林道夫 (1995) デカルト哲学の体系 自然学・形而上 学·道徳論. 勁草書房 : 東京, p. 454.

小林道夫（2009）科学の世界と心の哲学 心は科学で 解明できるか. 中央公論新社 : 東京, pp. 102, 156.

小泉義之（2007）兵士デカルト 戦いから祈りへ. 勁 草書房 : 東京, pp. 180-181.

久保正秋 (2010) 体育・スポーツの哲学的見方. 東海 大学出版会 : 秦野, pp. 128-137.

Laban, R. (1980) The mastery of movements. Macdonald et Evans: London, pp. 18-81.

Latchaw, M. and Egstrom, G. (1969) Human movements: with concepts applied to children's movements activities. Prentice-Hall: Englewood Cliffs, N.J.

Lawther, J.D. (1968) The Learning of physical skills. Prentice-Hall: Englewood Cliffs, N.J. pp. 103-121.

ロディス $=$ ロヴィス：小林道夫 ·川添信介訳 (1990) デカルトの著作と体系. 紀伊国屋書店 : 東京, p. 424.

Lodis=Lewis, G. (1998) La Morale de Descartes. Presses universitaires de France: Paris, p. 72.

Meinel, K. und Schnabel, G. (1977) Bewegungslehre. Volk und Wissen Volkseigener Verlag: Berlin, S. 59220 .

三輪 正 (1985) 習慣と理性一一近代フランス哲学研 究. 晃洋書房 : 京都, pp. 50-51.

持田辰郎（1992）静かな情念——デルトにおける徳と 情念一一. 伊藤勝彦 - 坂井昭宏編 情念の哲学. 東 信堂 : 東京, pp. 105-106.

Morgan, V.G. (1994) Foundations of cartesian ethics.

Humanities press: New Jersey, pp. 163, 193-194.

中村雄二郎 (1997) 哲学入門. 中央公論社 : 東京, p. 95.

中村雄二郎（2007）共通感覚論. 岩波書店 : 東京, pp. 260-263.

中村雄二郎 (2012) 知の百家言. 講談社 : 東京, pp. 166.

佐藤臣彦（2003）身体教育を哲学する一一体育哲学叙 
説一. 北樹出版 : 東京, p. 193.

シェフラー, A. • シュミット, S. : 三木明徳ほか訳 (2002) からだの構造と機能. 西村書店 : 東京, p. 184.

Sutton, J. (2000) The body and the brain. In: Gaukroger, S. (Ed.) DESCARTES' NATURAL PHILOSOPHY. Routledge Studies in Seventeenthcentury philosophy 3 Routledge: London, New York, pp. 697-722.
瀧澤文雄（2011）身体的思考における下位〔動作〕の 役割. 体育学研究, 56(2): 391-402.

谷川多佳子 (1995) デカルト研究 理性の境界と周縁. 岩波書店 : 東京, p. 269.

$\left(\begin{array}{l}\text { 平成 } 25 \text { 年 } 3 \text { 月 } 25 \text { 日受付 } \\ \text { 平成 } 25 \text { 年 } 9 \text { 月 } 20 \text { 日受理 }\end{array}\right)$

Advance Publication by J-STAGE

Published online 2013/11/29 